\title{
Maturity of Cabernet Sauvignon berries from grapevines grown with two different training systems in a new grape growing region in Brazil
}

\author{
Leila D. Falcão ${ }^{1}$, Eduardo S. Chaves ${ }^{1}$, Vivian M. Burin¹, Ana Paula Falcão, \\ Eliana F. Gris ${ }^{1}$, Valdir Bonin ${ }^{2}$, and Marilde T. Bordignon-Luiz ${ }^{1}$ \\ ${ }^{1}$ Departamento de Ciência e Tecnologia de Alimentos CAL/CCA, Universidade Federal de Santa Catarina; \\ Rododovia Admar Gonzaga, 1346, Itacorubi, Florianópolis, SC, Brazil. \\ ${ }^{2}$ EPAGRI -Empresa de Pesquisa e Extensão Agropecuária de Santa Catarina. Rua José Araújo Lima, 102, \\ Jardim Caiçara, São Joaquim, SC, Brazil.
}

\begin{abstract}
L.D. Falcão, E.S. Chaves, V.M. Burin, A.P. Falcão, E.F. Gris, V. Bonin, and M.T. BordignonLuiz. 2008. Ripening of Cabernet Sauvignon berries from grapevines grown with two different training systems and environmental conditions in a new grape growing region in Brazil. Cien. Inv. Agr. 35(3):271-282. The wine grape (Vitis vinifera) cv. Cabernet Sauvignon has recently been introduced at a 1160 m altitude in the São Joaquim area (Santa Catarina State, Southern Brazil). The aim of this work was to evaluate the maturation of Cabernet Sauvignon grapes subjected to a Y training system or a vertical shoot positioning trellis (VSP). Grapes were sampled at 10-day intervals throughout their maturation during two consecutive vintage years (2004-2005 and 2005-2006). Climate data were assessed. Based on the results obtained in both vintage years at maturity, titratable acidities (TA) ranged from 0.67 to $0.85 \mathrm{~g} \cdot 100 \mathrm{~mL}^{-1}$ of tartaric with the $\mathrm{pH}$ fluctuating between 3.49 and 3.77. The maturation index (total soluble solids/TA) at maturity ranged from 26 to 35 , and was always higher for berries from the VSP system. Significant differences were observed for the anthocyanin content (TMA) and total polyphenol index (TPI) values that may be attributed to differences in vintage year and climate conditions. Climatic conditions strongly influenced the grape quality, and it is important to note that São Joaquim is a warm region according to the Winkler scale, with 1668-1944 GDD ${ }^{\circ} \mathrm{C}$. Under these environmental conditions, the VSP system provided better results for TSS, berry weight and acidity than the Y system, which could be seen more clearly in 2005-2006 due to lower rainfall.
\end{abstract}

Key words: Cabernet Sauvignon grape, ripening, mesoclimate, vertical shoot positioning trellis, Y system,

\section{Introduction}

Grape maturity can be defined as the physiological age of the grapevine berry (Vitis vinifera L.) (Bisson, 2001). Water, sugars, and nitrogen compounds are transported to the berry via the phloem during maturation. Sucrose is hydrolyzed into glucose and fructose in the berry, increasing the sugar content, which is often used to assess maturity

Received 31 January 2008. Accepted 15 August 2008.

${ }^{1}$ Corresponding authors: bordign@eca.ufsc.br
(Watson, 2003). According to Fang and Qian (2006), the concentrations of most aromaactive compounds increase along with grape maturity, but the opposite is true for esters. Phenolic compound accumulation has also been used to determinate the optimal maturity, and these compounds have been strictly related to the vine water status during grape maturation (Esteban et al., 2001; Ojeda et al., 2002). In general, water deficit has a clear positive effect on berry phenolic composition. A combination of sugar and acid concentrations and $\mathrm{pH}$ are generally used to determine whether the grapes have reached optimum ripeness (Hunter et al., 
1991; Bergqvist et al., 2001). However, it has always been difficult to determine when the grapes are best for wine.

Cabernet Sauvignon is a red cultivar from Bordeaux, France that has been spread worldwide. Important research to improve the quality and adaptation of this grapevine cultivar is being conducted in the USA (Crippen and Morrison, 1986; Nuzzo and Matthews, 2006), Chile (Muñoz et al., 2002), Australia (Petrie and Clingeleffer, 2006), New Zealand (Tesic et al., 2001) and South Africa (Hunter et al., 1991).

There is a continuing research effort by viticulturists toimprove wine grape management through vine spacing, training, trellising, and pruning practices. Grapevines are trained to a specific system to favor the sunlight in order to maximize quality and facilitate cultivation, harvesting, and diseases control. As the overall physiological effects of a training system depend on specific meso- and microclimatic conditions, it is difficult to extrapolate results to other growing areas. Even so, the principles of regulating vine performance remain the same (Baeza et al., 2005).

All training systems have some basic requirements, such as: 1 . Optimal light interception: the grapes need light to develop desirable, colored berries (Weaver and Mccune, 1960). Photosynthesis in the grape leaves results in the production of sugars and other products essential to high quality fruit development; 2. Optimal air movement: sufficient airflow should be established by the training system to reduce potential disease problems; and 3 . Optimal management: enabling easy harvest.

Vine-training systems can be classified in a number of ways. In France, it is common to classify vines as low trained ("vignes basses") or high trained ("vignes hautes"). For low trained vines, the trunk is usually less than $0.5 \mathrm{~m}$ to $0.2 \mathrm{~m}$ high. Such training systems are more economical, and are suited to lowervigor vineyards. Grape maturity may benefit because clusters are close to the ground, but both manual harvest and pruning are much less comfortable operations, and vines may also be prone to diseases.
In Santa Catarina State, where V. vinifera grapes have been cultivated since 2000, the vertical shoot positioning trellis (VSP) is the most applied training system (Figure 1). Y is a vinetraining system similar to the $\mathrm{V}$ system, except that the trunk of the vine forms the vertical part of the letter Y (Figure 1). Mechanical harvest is easier in the VSP system than the Y system and it is more easily extended and less expansive than the Y system. Also, the simplicity of the VSP system facilitates the manipulation of the leaf canopy in order to alter the microclimate conditions around the vines during the growing season. The VSP system provides more shade than the $\mathrm{Y}$ system, which is a disadvantage considering that shade should be reduced to improve grape quality. The VSP system is used in Bordeaux, Burgundy and Champagne in France, using a short trunk with close planting to increase vine stress. It is also used with a higher trunk in Alsace, Germany and North and South America.

The aim of this work was to evaluate the effect of the VSP and Y systems on the maturity of Cabernet Sauvignon grapes in a new grape growing region in Brazil.

\section{Materials and methods}

\section{Plant growth}

The experiment was conducted in a single $V$. vinifera vineyard cv. Cabernet Sauvignon, in São Joaquim (1,160 m a.s.l.), Santa Catarina State, Southern Brazil (28¹9'0' S, 49³4'51", $\mathrm{W})$. Five grapevine rows trained in the $\mathrm{Y}$ system and five other rows trained in the VSP system were grafted on Paulsen 1103 ( $V$. berlandierli Planch $x$ V. rupestris Scheele), clone R-5 (Figure 1). The vineyard was planted at $2.9 \times 1.3 \mathrm{~m}$ and $3.2 \times 1.3 \mathrm{~m}$ for the $\mathrm{Y}$ and VSP systems, respectively. Yields from the 4to 5 year-old vineyard ranged from 5 to $8 \mathrm{t}^{\mathrm{h}} \mathrm{ha}^{-1}$. Berry maturity was evaluated in 2004-2005 and 2005-2006 using 30 vines selected randomly in the three central rows for each training system.

\section{Soil analyses}

Soil analyses were made according to official methods (USDA, 2005). The color notations 
A

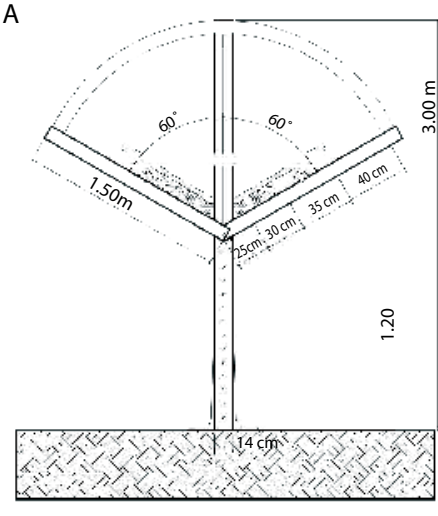

B

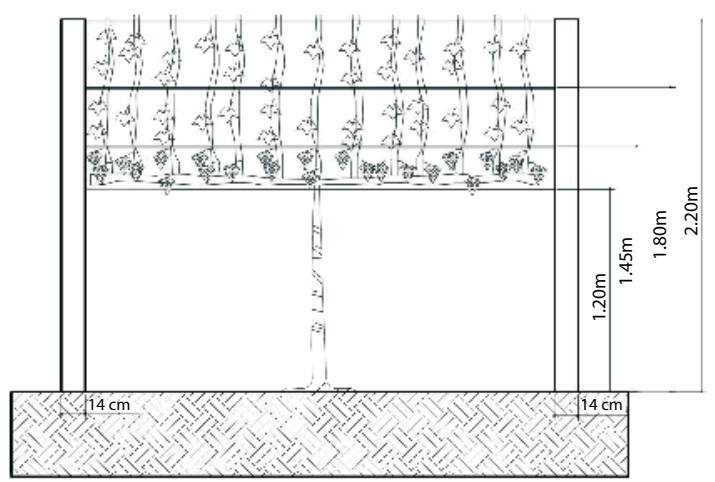

Figure 1. Grapevine training systems. A. Y system and B. Vertical shoot positioning trellis (VSP).

were determined per horizon and converted into color indices using the soil Munsell color chart (Munsell Colour Company, Baltimore, MD, USA, 1990).

\section{Climate data}

The maximum, minimum and mean temperatures, and the rainfall were obtained from the meteorological weather station located $4 \mathrm{~km}$ from the vineyard in 2004-2005 and 2005-2006. Growing degree-days (GDD), using a $10^{\circ} \mathrm{C}$ base, were calculated from the mean daily temperature $(\mathrm{T})$ as $\mathrm{GDD}=\sum\left(\mathrm{T}_{>10^{\circ} \mathrm{C}}\right.$ $\left.-10^{\circ} \mathrm{C}\right)$, starting at budbreak until harvest.

\section{Berry samples and commercial maturity analysis}

The samplings began at véraison when approximately $50 \%$ of the berries were red. The vineyard was sampled five to seven times at 10day intervals in 2004-2005 and 2005-2006, respectively. All samples were collected from plots of 30 vines distributed in two central rows. Each sample consisted of a total of 240 berries, eight berries per vine. Harvest started when each treatment reached commercial maturity, with total soluble solids (TSS) of approximately $24 \%$ in 2004-2005 and 22\% in 2005-2006. The berry sets collected were immediately counted, weighed, and submitted to physicochemical analysis. Each 240-berry sample was divided into three sub-samples of 90,90 and 60 berries. A sub-sample of 70 berries was kept at $-20^{\circ} \mathrm{C}$ for future analysis. The juice for berry maturity analysis was squeezed from a fresh randomly selected 30-berry sample in triplicate $(=90$ berries). Juice samples were analyzed for $\mathrm{pH}$ and titratable acidity (TA) using $0.1 \mathrm{M} \mathrm{NaOH}$, and TSS (Abbe refractometer at $25^{\circ} \mathrm{C}$, AusJena, model 265085) (OIV, 1990).

\section{Berry composition}

Anthocyanin extraction and quantification. Samples consisting of 30 berries were carefully selected in triplicate ( $=90$ berries) from the berry sets. The skins were separated from the pulp, weighed and used for anthocyanin extraction. The grape skins were macerated overnight in methanol (p.a):12 N HCl (99:1) in the dark at $4.0 \pm 1{ }^{\circ} \mathrm{C}$. The extracting skin:solvent ratio of 1:5 (w/v) was used. Then, extracts were filtered through Whatman No. 1 filter paper in a Büchner funnel. The total monomeric anthocyanin (TMA) quantifications were determined using the $\mathrm{pH}$-differential method (Giusti and Wrolstad, 2001), using $\varepsilon=28000$ and MW = 529 (Amerine and Ough, 1976).

Total polyphenol index (TPI). The same anthocyanin quantification extract was used for TPI determination using the Folin-Ciocalteu assay, with absorbance readings at $760 \mathrm{~nm}$. The total phenolic content was expressed as gallic 
acid equivalents (GAE) in milligrams per 100 grams of fresh grape skins.

\section{Berry color measurements}

Color was determined directly by spectrophotometry using a 1:10 dilution of the methanolic skin extracts. A UV-Vis Hitachi spectrophotometer (U2010) (Tokyo, Japan) was used at 420, 520 and $620 \mathrm{~nm}$ wave lengths, with a $1 \mathrm{~mm}$ pathlength cuvette. The color index (CI) was calculated according to $\mathrm{CI}=$ $\mathrm{Abs}_{420}+\mathrm{Abs}_{520}+\mathrm{Abs}_{620}$ (Glories, 1984). The hue was calculated as Hue $=\mathrm{Abs}_{420} / \mathrm{Abs}_{520}$.

\section{Berry seed number}

In the 2005-2006 vintage, the number of grape seeds was counted in 100 berries at 10-d intervals during the maturation period.

\section{Design and statistical analysis}

Data were analyzed for variance following a completely randomized design with three replicates, each consisting of 30 vine plots. Means were separated according to Tukey's test. All statistical analyses were performed with Statistica 6 (StatSoft Inc., Tulsa, OK, USA, 2001).

\section{Results and discussion}

\section{Environmental conditions}

Environmental factors are important to obtain high quality $V$. vinifera grapes for winemaking. The wine style that a region produces is the result of the specific local climate and soil characteristics. Climatic changes therefore have the potential to bring about changes in wine styles. In the present study, the $\mathrm{Y}$ and VPS training systems were evaluated in the same vineyard under the same climate and soil type conditions. The climatic data of the 20042005 and 2005-2006 growing seasons can be considered as typical climatic conditions for the geographical zone of São Joaquim where this experiment was conducted (Table 1). At véraison in 2004-2005, rainfall was almost three times higher than for the 2005-2006 vintage, wind speed was near $2 \mathrm{~km} \cdot \mathrm{h}^{-1}$, and there was about $1254 \mathrm{~h}$ of sunshine (Table 1). Temperatures were more favorable for grape growing in 2005-2006 than in 2004-2005. The minimum GDD level of heat accumulation of $1093 \mathrm{GDD}^{\circ} \mathrm{C}$ was reached in the vineyard site in both vintage years (Amerine and Winkler, 1944). According to the Amerine and Winkler (1944) scale, São Joaquim is classified as Region III $\left(1668-1944 \mathrm{GDD}^{\circ} \mathrm{C}\right)$, which is considered a warm region according to this scale. Similar heat accumulation occurs in other grape growing regions in the world such as the Rhône Valley, France. Climate data from véraison to harvest in both the 2004-2005 and 2005-2006 vintages is given in Figure 2.

Cabernet Sauvignon grapes are grown in temperate to hot regions with mean temperatures varying from 16.5 to $19.5^{\circ} \mathrm{C}$ (e.g., Bordeaux, France; Napa Valley, California) (Jones 2007). São Joaquim showed mean daily temperatures from 15.9 to $17.9^{\circ} \mathrm{C}$ for the $2004-2005$ and 2005-2006 growing seasons, confirming that São Joaquim is a suitable region for planting Cabernet Sauvignon. Nevertheless, further research is need to study wine quality.

In São Joaquim, the dominant relief is steady and the altitudes range from approximately 1100 to $1400 \mathrm{~m}$, with the experimental vineyard at $1160 \mathrm{~m}$ a.s.l. The soil type is classified as Inceptisols and placed in the soil with basaltic, extrusive origin material and igneous rock (USDA, 2005). Soil color was a very dark grayish brown $(10 \mathrm{YR} / 3 / 2)$, soil texture was clay-silty, and soils were well drained, soft, friable, and 'plastic', with high water retention capacity. In natural conditions it is a soil with little availability of nutrients and high acidity with aluminum. However, after correction it becomes epitrophic (Table 2).

The soil chemical composition of the experimental vineyard after correction is suitable for planting grapevines. The results of $\mathrm{pH}$ analyses showed values slightly acidic in the epipedons (horizon A) and acidic in the subsurface of the soils for all sites (Table 2). Organic matter and potassium content in the epipedons section were considerably high, which increases soil fertility; consequently, grapevine nutrition should be high. Exchangeable 
Table 1. Climatic parameters that characterized the experimental area (1160 m a.s.1.) in São Joaquim, SC, Brazil in the 2004-2005 and 2005-2006 growing seasons.

\begin{tabular}{lcrc}
\hline Parameters & \multicolumn{2}{c}{ Vintage years } & $\begin{array}{c}\text { Average from 01 Jan, 1955 } \\
\text { to 07 Jan, 2006 }\end{array}$ \\
\cline { 2 - 3 } & $2004-2005^{1}$ & $2005-2006^{1}$ & 1364.3 \\
Rainfall (Sep-Apr), mm & 913.0 & 417.0 & 414.0 \\
Total rainfall from véraison to harvest ${ }^{3}$, mm & 292.0 & 112.0 & - \\
Degree days (base $10^{\circ} \mathrm{C}$ ) (Sep-Apr) & 1735.0 & 1680.0 & 20.0 \\
Mean maximum temperatures (Sep-Apr), ${ }^{\circ} \mathrm{C}$ & 23.5 & 22.3 & 14.2 \\
Mean daily temperatures (Sep-Apr), ${ }^{\circ} \mathrm{C}$ & 17.9 & 15.9 & 10.7 \\
Mean minimum temperatures (Sep-Apr), ${ }^{\circ} \mathrm{C}$ & 12.3 & 11.1 & 8.7 \\
Mean daily thermal amplitude (Sep-Apr), ${ }^{\circ} \mathrm{C}$ & 11.6 & 11.2 & 16.0 \\
Mean daily temperature from véraison to harvest ${ }^{3},{ }^{\circ} \mathrm{C}$ & 18.6 & 19.0 & 1253.5 \\
Cumulative sunshine (Sep-Apr), $\mathrm{h}$ & 1300.7 & 1372.8 & \\
\hline
\end{tabular}

${ }^{1}$ From 14 Sep 2004 to 08 Apr 2005, and from 02 Sep 2005 to 28 Apr 2006.

${ }^{2}$ Data from a meteorological station placed $4 \mathrm{~km}$ from the experimental vineyard.

${ }^{3}$ Véraison 15 Feb 2005 and 28 Feb 2006 and harvest 08 Apr 2005 and 28 Apr 2006.

A

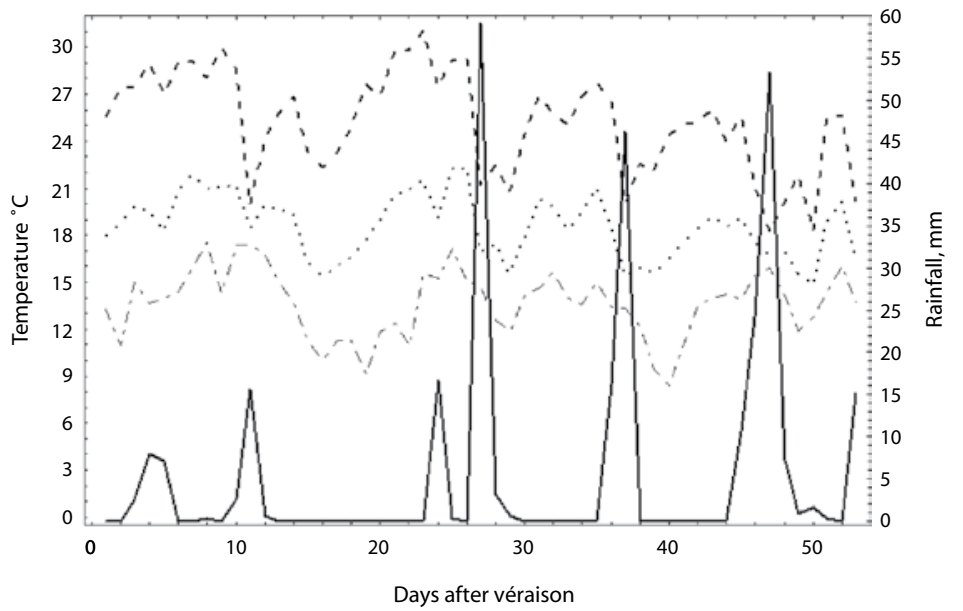

B

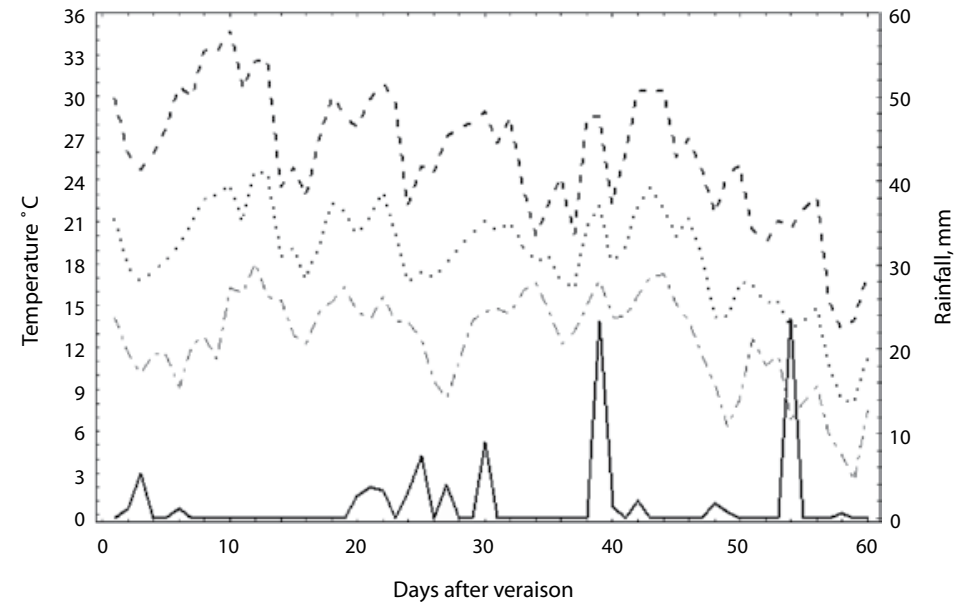

$\begin{array}{ll}--- \text { minimum temperature } \quad \ldots . . . & \text { mean temperature } \\ \text {--- maximum temperature } \quad-\text { rainfall }\end{array}$

Figure 2. Mesoclimate parameters determined from véraison to harvest in a São Joaquim vineyard at 1,160 m a.s.1. A. 2004-2005 and B. 2005-2006. 
Table 2. Soil analyses of the experimental vineyard located at $1160 \mathrm{~m}$ a.s.l. in São Joaquim, SC, Brazil.

\begin{tabular}{lrr}
\hline \multirow{2}{*}{ Parameters } & \multicolumn{2}{c}{ Inceptisols $^{1}$} \\
\cline { 2 - 3 } & $0-20 \mathrm{~cm}$ & $20-40 \mathrm{~cm}$ \\
\hline \multirow{2}{*}{ Clay, \% } & 48.0 & 70.0 \\
Organic matter, \% & 5.2 & 3.3 \\
$\mathrm{pH}$ & 6.1 & 5.2 \\
Phosphorus available, $\mathrm{mg} \cdot \mathrm{kg}^{-1}$ & 3.7 & 1.0 \\
Potassium exchangeable, $\mathrm{mg} \cdot \mathrm{kg}^{-1}$ & 209.0 & 63.0 \\
Magnesium exchangeable, $\mathrm{mg} \cdot \mathrm{kg}^{-1}$ & 4.2 & 1.6 \\
Aluminium available, $\mathrm{mg} \cdot \mathrm{kg}^{-1}$ & 0.0 & 0.8 \\
Calcium available, $\mathrm{mg} \cdot \mathrm{kg}^{-1}$ & 9.9 & 3.6 \\
Sum of bases $(\mathrm{Ca}+\mathrm{Mg}+\mathrm{H}), \mathrm{cmol}^{-1} \mathrm{~kg}^{-1}$ & 14.6 & 5.4 \\
Saturation of bases $(\mathrm{Ca}+\mathrm{Mg}+\mathrm{H}), \%$ & 68.0 & 51.0 \\
Cation exchange capacity, $\mathrm{cmol} \cdot \mathrm{kg}^{-1}$ & 21.4 & 10.5 \\
\hline
\end{tabular}

${ }^{1}$ Soil type was classified as Inceptisols on the basis of the U.S. soil taxonomy (USDA, 2005).

potassium, which has a positive effect on yield, plant vigor, and drought resistance (Chone et al., 2001), was found in high levels in this soil. The clay-silty texture contributes to a high water-retention capacity of this Inceptisols.

\section{Berry composition during maturation}

The most common indicators of grape quality are $\mathrm{pH}$, TSS and TA (Amerine et al., 1980). However, these are not the only factors that effect winemaking. Thus, several other parameters were evaluated from verraison to harvest to assess the main grape characteristics produced in this new grape region of Brazil.

The berry weight and TSS evolution during maturation of Cabernet Sauvignon grapes in both the 2004-2005 and 2005-2006 vintages are summarized in Figure 3. It is known that the berry weight evolution during grape maturation is directly related to the number of seeds, to the increase of TSS and to berry water content. In the 2005-2006 vintage, the mean number of seeds was 1.31 and 1.43 seed-berry ${ }^{-1}$ for grapevines subjected to the VSP and Y training systems, respectively. In both vintage years, during the maturation period berries from the Y system were weightier than berries from the VSP training system, which is in accordance with the slightly higher number of seeds per berry obtained from the VSP system. Generally, a strong increase in berry weight was obtained from 10 to $40 \mathrm{~d}$ after véraison, with a minor increase thereafter. Independent of the training system, berry weight was below $2.0 \mathrm{~g}$ at harvest, which is considered small (OIV, 1985).

The TSS content increased mainly during the berry maturation period (Figure 3), since during earlier berry growth stages sugars are used for growth and seed development. After véraison, a metabolic change occurs enabling sugar accumulation in the berry during maturation (Figure 3). No significant differences in TSS content were obtained between grapes produced in the $\mathrm{Y}$ system and grapes produced in the VSP system. Differences in TSS among vintage years can be attributed to the GDD in 20042005 (1735), which was higher than in 20052006 (1680), and to the mean daily temperature in $2004-2005\left(17.9^{\circ} \mathrm{C}\right)$, which was higher than in $2005-2006\left(15.9^{\circ} \mathrm{C}\right)$. However, these differences may not have an enological impact, since the TSS difference between the systems in 2005-2006 was 0.6\% (Table 3). These results are similar to those obtained by Baeza et al. (2005) where significant differences were found in the TSS of Tempranillo grapes grown in four training systems in 1990 and 1992, but not in 1991 vintages. Auvray et al. (1999) did not observe differences in final TSS values for grapevines grown using different systems.

$\mathrm{pH}$ is becoming increasingly recognized for its important contribution to wine quality because it plays a key role in prevention of microbial spoilage, malolactic fermentation occurrence and color stability of wines. In 2004-2005 the average temperature values were higher than in 
2005-2006 (Table 1); pH values were also higher in 2004-2005 (Figure 4). Butzke and Boulton (1997) reported that overripe grapes or a warm climate can result in higher $\mathrm{pH}$ and low acid concentrations due to the respiration of organic acids. As a general trend, the $\mathrm{pH}$ increased along with the sugar concentration as grapes matured (Figures 3 and 4). In contrast, titratable acidity (TA) declined during maturation (Figure 4). A positive $\mathrm{pH}$ average evolution was observed from $\mathrm{pH} 2.8$ at véraison to $\mathrm{pH}$ 3.8 at harvest. The highest increase occurred at the beginning of maturation, concurrent with a sharp decline in TA values. At the beginning of maturity there was a high titratable acidity in the berries under both systems (means of 1.3$1.8 \mathrm{~g}$ of tartaric acid/100 mL of must). In the first $20 \mathrm{~d}$ of maturation, TA dropped by 0.45 $\mathrm{g} \cdot \mathrm{L}^{-1}$ in 2004-2005 and $0.90 \mathrm{~g} \cdot \mathrm{L}^{-1}$ in 2005-2006, on average, every $10 \mathrm{~d}$. After this period acid losses occurred at a rate of $0.07 \mathrm{~g} \cdot \mathrm{L}^{-1}$ every 10 $\mathrm{d}$, for both vintage years. There were small differences in the $\mathrm{pH}$ of the must between training systems at maturity, which were only significant in 2005-2006 (Table 3). Auvray et al. (1999) did not find any significant differences in $\mathrm{pH}$ levels in grape must from different training systems despite significant differences in titratable acidity imposed by the systems.

The $\mathrm{pH}$ values obtained at harvest ranged from $\mathrm{pH} 3.5$ to $\mathrm{pH} 3.8$ (Figure 4). According to Amerine and Ough (1976), wines with a $\mathrm{pH}$ above 3.6 may have stability problems. In general, $\mathrm{pH}$ and $\mathrm{TA}$ values from véraison to harvest were very similar and were independent of the training system. As expected, TA decreased with grape maturation (Figure 4), and a sharp decrease was observed during the first $20 \mathrm{~d}$ after véraison. This may be attributed to berry respiratory processes that involve malic acid and also to organic acid dilution due to an increase in berry volume (Borgogno et al., 1984).

It is known that the increase in total grape
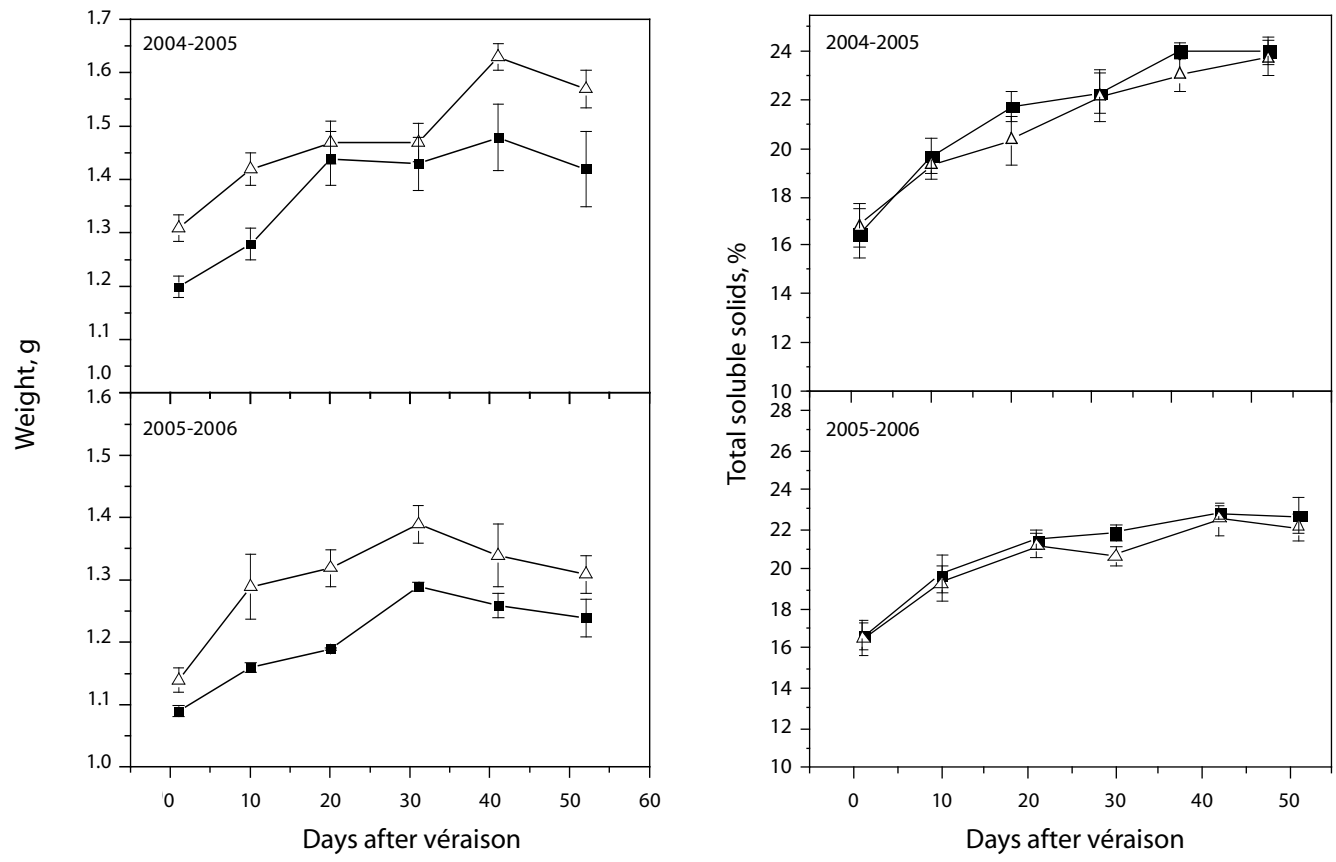

Figure 3. Berry weight evolution and total soluble solids obtained from véraison to harvest in 2004-2005 and 2005-2006 vintages for grapevines (Vitis vinifera) Cabernet Sauvignon conducted in Y $\left(-\Delta^{-}\right)$and VSP ( - ) training systems. Means of three replicates, \pm standard deviation. 

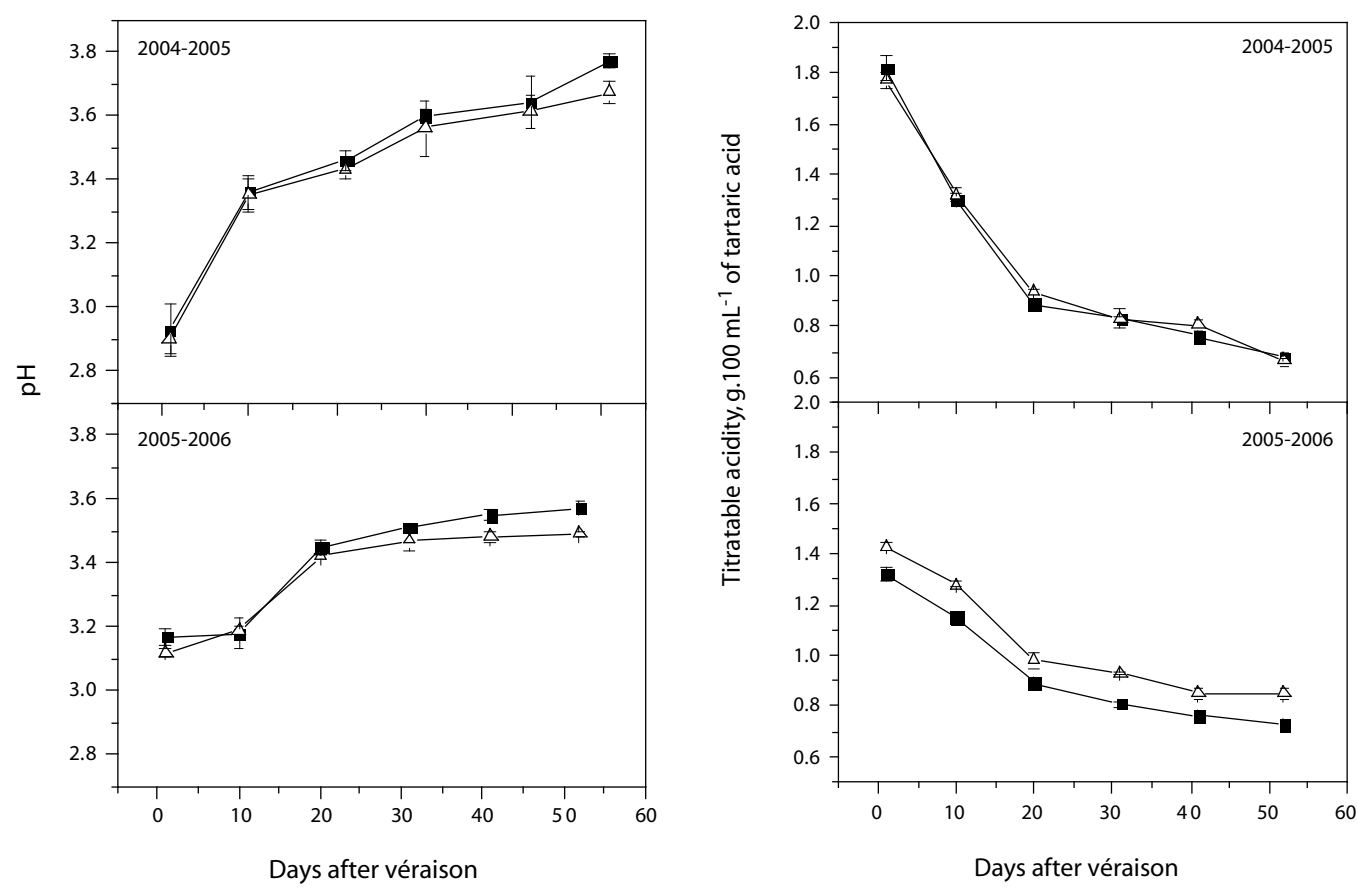

Figure 4. Evolution of $\mathrm{pH}$ and titratable acidity from véraison to harvest in 2004-2005 and 2005-2006 vintages for grapevine (Vitis vinifera) Cabernet Sauvignon conducted in Y $(-\Delta-)$ and VSP (- - ) training systems. Means of three replicates, \pm standard deviation. Titratable acidity was expressed as tartaric acid.

phenolic content is associated with berry maturation (Mateus et al., 2002). In grapes, anthocyanin synthesis begins at véraison and its accumulation occurs in the grape skins during the maturation period (Muñoz et al., 2002). In an analysis of principal components, phenolic content emerged as a key-defining factor of grape maturity (Gonzalez-San Jose, 1991).

The maturation index (MI) relates titratable acidity and sugar level and should be 30 to 32 (Gallander, 1983) or 37 to 38 (Amerine et al., 1980) for wine production. Except for the Y system in the 2005-2006 vintage, MI values above 30 were reached at maturity and differences between the VSP and Y systems were not significant (Table 3).

The total monomeric anthocyanins (TMA) and total polyphenols (TPI) in the 2004-2005 and 2005-2006 vintages had a positive evolution at berry maturation (Figure 5). The maximum TMA and TPI values were obtained $40 \mathrm{~d}$ after véraison for both training systems. These results are in accordance with a previous report on grapevines cvs. Touriga Nacional and Touriga Francesa, where anthocyanin content was at its maximum approximately $40 \mathrm{~d}$ after véraison (Mateus et al., 2002). In the 2004-2005 vintage, a sharp decline in anthocyanin content was obtained $40 \mathrm{~d}$ post-véraison, decreasing from 389 to 275 and from 448 to $300 \mathrm{mg} \cdot 100 \mathrm{~g}^{-1}$ grape skins, for the Y and VSP systems, respectively. Similarly, TPI values dropped from 835 to 646 and from 874 to $589 \mathrm{mg} \cdot 100 \mathrm{~g}^{-1}$ grape skins based on GAE, $40 \mathrm{~d}$ post-véraison. Heavy rainfall between 40 and $50 \mathrm{~d}$ after véraison may at least partially explain, by a "dilution effect", the drop in anthocyanin and TPI content obtained in the 2004-2005 growing season (Figure 2B). Other work has also described dramatic effects of the environment and culture conditions on anthocyanin accumulation (Ryan and Revilla, 2003; De La Hera Orts et al., 2005).

The color evolution during grape maturation was affected by vintage year (Figure 6). However, during véraison a difference in color 
Table 3. Effect of training system and vintage year on berry composition of grapevine (Vitis vinifera) cv. Cabernet Sauvignon obtained at harvest in a commercial vineyard in São Joquim, Southern Brazil.

\begin{tabular}{|c|c|c|c|c|}
\hline \multirow[t]{3}{*}{ Berry characteristics } & \multicolumn{4}{|c|}{ Growing seasons } \\
\hline & \multicolumn{2}{|c|}{ 2004-2005 } & \multicolumn{2}{|c|}{$2005-2006$} \\
\hline & $\begin{array}{c}\text { VSP } \\
\text { system }^{1}\end{array}$ & $\begin{array}{c}\mathrm{Y} \\
\text { system }^{1}\end{array}$ & $\begin{array}{c}\text { VSP } \\
\text { system }^{1}\end{array}$ & $\begin{array}{c}\text { Y } \\
\text { system }^{1}\end{array}$ \\
\hline Weight, $g$ & $1.4 \pm 0.10 \mathrm{a}^{3}$ & $1.6 \pm 0.10 b^{3}$ & $1.2 \pm 0.30 \mathrm{a}^{3}$ & $1.3 \pm 0.20 \mathrm{a}^{3}$ \\
\hline $\mathrm{pH}$ & $3.77 \pm 0.09 \mathrm{a}$ & $3.67 \pm 0.02 \mathrm{a}$ & $3.57 \pm 0.03 \mathrm{a}$ & $3.49 \pm 0.01 b$ \\
\hline Total soluble solids, $\%$ & $23.9 \pm 0.70 \mathrm{a}$ & $23.7 \pm 0.40 \mathrm{a}$ & $22.7 \pm 0.3 \mathrm{a}$ & $22.1 \pm 0.2 b$ \\
\hline Titratable acidity, $\mathrm{g} \cdot 100 \mathrm{~mL}^{-1}$ & $0.68 \pm 0.04 \mathrm{a}$ & $0.67 \pm 0.02 \mathrm{a}$ & $0.73 \pm 0.03 \mathrm{a}$ & $0.85 \pm 0.03 b$ \\
\hline Maturation index ${ }^{2}$ & $35 \pm 3.4 \mathrm{a}$ & $31 \pm 1.0 \mathrm{a}$ & $31 \pm 0.60 \mathrm{a}$ & $26.0 \pm 1.20 \mathrm{~b}$ \\
\hline Total monomeric anthocyanins, $\mathrm{mg} \cdot 100 \mathrm{~g}^{-1}$ of grape skins & $300 \pm 1.0 \mathrm{a}$ & $275 \pm 2.0 \mathrm{~b}$ & $555 \pm 5.0 \mathrm{a}$ & $575 \pm 8.0 \mathrm{~b}$ \\
\hline Total polyphenols ${ }^{2}, \mathrm{mg} \cdot 100 \mathrm{~g}^{-1}$ of grape skins & $589 \pm 2.0 \mathrm{a}$ & $646 \pm 47.0 \mathrm{a}$ & $905 \pm 42 \mathrm{a}$ & $1003 \pm 23 a$ \\
\hline Color intensity $^{2}$ & $3.01 \pm 0.01 \mathrm{a}$ & $2.70 \pm 0.01 b$ & $4.49 \pm 0.06 \mathrm{a}$ & $5.39 \pm 0.02 b$ \\
\hline Color tonality ${ }^{2}$ & $1.28 \pm 0.02 \mathrm{a}$ & $1.38 \pm 0.03 \mathrm{a}$ & $1.37 \pm 0.01 \mathrm{a}$ & $1.14 \pm 0.02 b$ \\
\hline
\end{tabular}

${ }^{1}$ Grapevines, grafted on Paulsen 1103 (V. berlandierli $x$ V. rupestris), clone R-5, were grown in a vertical shoot positioning trellis system (VSP) or a Y system.

${ }^{2}$ Maturation index $=$ total soluble solids/titratable acidity. Color intensity $=\mathrm{Abs}_{420}+\mathrm{Abs}_{520}+\mathrm{Abs}_{620}$. Color tonality $=\mathrm{Abs}_{420} / \mathrm{Abs}_{520}$. $\operatorname{Total}$ polyphenols index as gallic acid equivalent.

${ }^{3}$ Means, \pm standard deviations, followed by different letters in the same line, for each vintage, are significantly different according to Tukey's test $(\mathrm{p}<0.05)$.

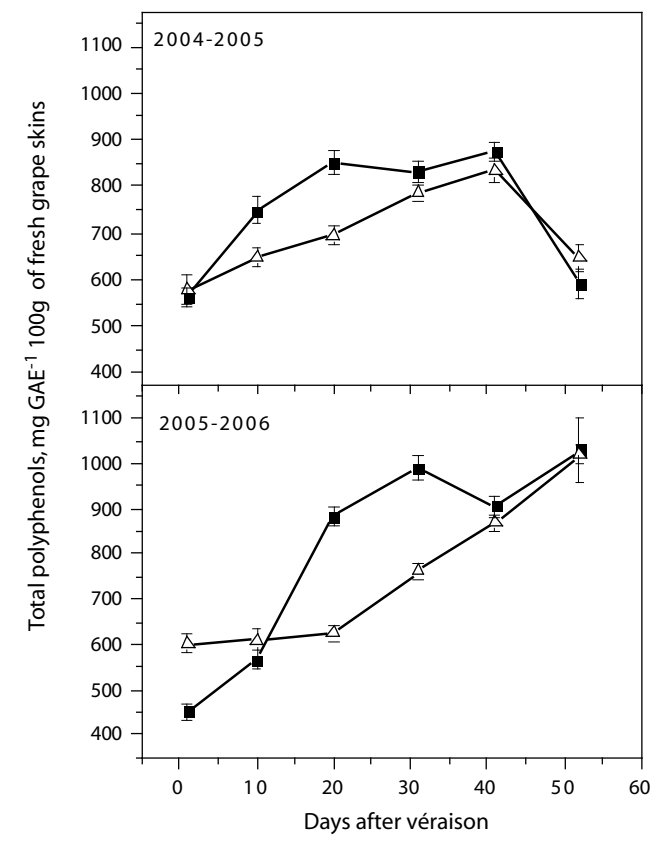

Figure 5. Total monomeric anthocyanins and total polyphenols evolution from véraison to harvest in 2004-2005 and 2005-2006 vintages for grapevine (Vitis vinifera) Cabernet Sauvignon conducted in $\mathrm{Y}(\triangle-)$ and VSP (—-) training systems. Means of three replicates, \pm standard deviation. was obtained between the training systems. Color intensity values were higher in 2005-2006 than in 2004-2005, which appears independent of the training system (Figure 7, Table 3). It is interesting to note that for a premium quality wine, high CI values and low berry weight are desirable.

Most berry composition parameters were strongly affected at harvest by vintage year. This may be explained by the marked difference in climatic conditions between 2004-2005 and 2005-2006 (Table 1, Figure 2). In 2004-2005 only TMA and CI values were significantly different between the systems, with VSP giving the best results. In 2006, low rainfall during maturation made the differences between the training systems more evident for almost all parameters evaluated (Table 3). For this vintage, higher values for TMA and CI were obtained with the $\mathrm{Y}$ system. More vintages should be evaluated to reach a conclusion on the better training system in relation to chromatic characteristics and anthocyanins content. In relation to TSS and MI, the VSP always showed smaller values, which were significant only in 2006.

In conclusion, the rainfall index between véraison and harvest had a strong influence 

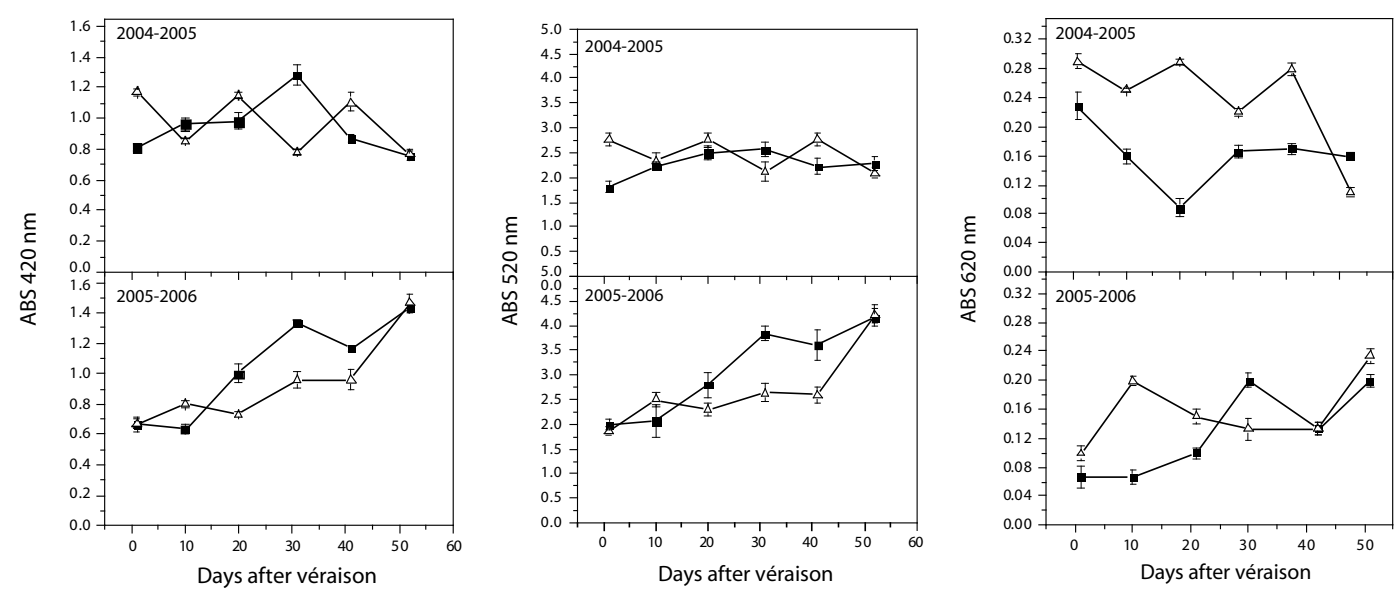

Figure 6. Color evolution from véraison to harvest of grape berry Cabernet Sauvignon in 2004-2005 and 2005-2006

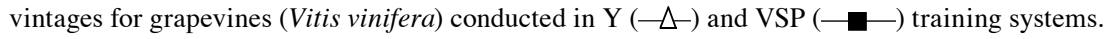

on berry quality. Future research must focus on evaluating the influence of training system on other grape metabolites, such as individual monomeric anthocyanins, malic acid and abscisic acid (ABA), a phytohormone that plays regulatory roles in a host of physiological processes in vines.

\section{Resumen}

El objetivo de este trabajo fue evaluar la maduración de uvas Cabernet Sauvignon bajo dos sistemas de conducción: sistema en Y y sistema de espaldera alta (VSP). Las viñas han sido cultivadas recientemente en la ciudad de São Joaquim, Estado de Santa Catarina (Brasil), a $1160 \mathrm{~m}$ de altitud. Las uvas fueron muestreadas para el análisis de su maduración en dos vendimias consecutivas, 2004-2005 y 2005-2006, cada 10 días, desde envero a cosecha. Parámetros del mesoclima también fueron determinados. Los resultados muestran que a madurez, en ambas vendimias los valores de acidez total (TA) fluctuaron entre 0,67 y 0,85 $\mathrm{g} \cdot 100 \mathrm{~mL}^{-1}$ de ácido tartárico y el pH entre 3,49 y 3,77 . En general, TA a madurez fue más baja en 2004-2005 que en 2005-2006. El índice de maduración (sólidos solubles totales/TA) en la madurez varió desde 26 a 35 , y fue más alto para bayas cultivadas en VSP. Se observaron diferencias significativas en los valores de antocianas y en el índice de los polifenoles totales (TPI); la vendimia y el clima explicaron las fuertes diferencias entre los niveles de antocianas y TPI. Las condiciones climáticas influyeron fuertemente en la calidad de la uva. En São Joaquim, el clima fue clasificado como 'Región III', según la Escala de Winkler, una región cálida (1668 a $\left.1944{ }^{\circ} \mathrm{C}\right)$. En general, el sistema VSP dio mejores resultados en lo referente a TSS, peso de la baya y acidez los que se percibieron más claramente en 2006 debido al menor nivel de precipitaciones.

Palabras clave: Cabernet Sauvignon, maduración, mesoclima, sistema de conducción en Y, espaldera.

\section{Acknowledgements}

We gratefully acknowledge Coordenação de Aperfeiçoamento de Pessoal de Nível Superior (CAPES) and Conselho Nacional de Desenvolvimento Científico e Tecnológico (CNPq) for financial support and to Hamilton Justino Vieira from EPAGRI - Florianópolis for technical assistence on climate data. We also thank Everson F. Suzin who supplied sections of their private vineyards and to Emílio Brighenti from EPAGRI-São Joaquim for auxilliary assistance collecting the grape samples. 


\section{References}

Amerine, M.A., and C.S. Ough. 1976. Análisis de Vinos y Mostos. Acribia, Zaragoza, Spain. 158 p.

Amerine, M.A., and R.A.J. Winkler. 1944. Composition and quality of musts and wines of California grapes. Hilgardia 15:493-673.

Amerine, M.A., H.W. Berg, R.E. Kunkee, C.S. Ough, V.L. Singleton, and A.D. Webb. 1980. The technology of wine making. Fourth edition. AVI Publishing Company Inc., Westport, Conn. $794 \mathrm{p}$.

Auvray, A., P. Baeza, C. Ruiz, and C.M. GonzálezPadierna. 1999. Influence de différentes géométries de couvert vegetal sur la composition du moût. Progres Agricole Viticole 166:253257.

Baeza, P., C. Ruiz, E. Cuevas, V. Sotés, and J.R. Lissarrague. 2005. Ecophysiological and agronomic response of Tempranillo grapevines to four training systems. Am. J. Enol Vitic 56:129-138.

Bergqvist, J., N. Dokoozlian, and N. Ebisuda. 2001. Sunlight Exposure and Temperature Effects on Berry Growth and Composition of Cabernet Sauvignon and Grenache in the Central San Joaquin Valley of California. Am. J. Enol. Vitic. 52:1-7.

Bisson, L. 2001. In search of optimal grape maturity. Practical Winery and Vineyard, Jul-Aug, p. 3243.

Borgogno, L., E. Taretto, P. Bologna, C. Arnulfo, and A. Morando. 1984. La maturazione dell'uva Vignevini 3:59-65.

Butzke, C.E., and R.B. Boulton. 1997. Acidity, pH and potassium for grapegrowers. Practical Winery and Vineyard, Sep-Oct, p. 10-16.

Chone, X., C. van Leeuwen, P. Chery, and P. Ribéreau-Gayon. 2001. Terroir influence on water status and nitrogen status of non-irrigated Cabernet Sauvignon (Vitis vinifera). Vegetative development, must and wine composition (example of a Medoc top estate vineyard, Saint Julien area, Bordeaux, 1997). S. Afr. J. Enol. Vitic. 22:8-15.

Crippen-Jr., D.D., and J.C. Morrison. 1986. The effects of sun exposure on the compositional development of Cabernet Sauvignon berries. Am. J. Enol. Vitic. 37:235-242.

De La Hera Orts, M.L., A. Martínez-Cutillas, J.M. López Roca, L.J. Pérez-Prieto, and E. GómezPlaza. 2005. Effect d'une irrigation déficitaire sur la teneur en anthocyanes des raisins et des vins issus du cépage Monastrell. J. Int. Sci. Vigne Vin 39:47-55.

Esteban, M.A., M.J. Villanueva, and J.R. Lissarrague. 2001. Effect of irrigation on changes in the anthocyanin composition of the skin of $\mathrm{cv}$ Tempranillo (Vitis vinifera L.) grape berries during ripening. J. Sci. Food Agric. 81:409-420.

Fang, Y., and M.C. Qian. 2006. Quantification of selected aroma-active compounds in Pinot Noir wines from different grape maturities. J. Agric. Food Chem. 54:8567-8573.

Gallander, J.F. 1983. Effect of grape maturity on the composition and quality of Ohio Vidal blanc wines. Am. J. Enol. Vitic. 34:139-141.

Glories, Y. 1984. La couleur des vins rouges 2ème partie-Mesure origine et interpretation. Conn. Vign Vin 18:253-271.

Gonzalez-San Jose, M.L., L.J.R. Barron, B. Junquera, and M. Robredo. 1991. Application of principal component analysis to ripening indices for wine grapes. J. Food Comp. Anal. 4:245-255.

Giusti,M.M., andR.E.Wrolstad.2001. Anthocyanins: characterization and measurement with UVvisible spectroscopy. Unit F1.2.1-13. In: R.E. Wrolstad (ed.). Current Protocols in Food Analytical Chemistry. John Wiley and Sons, NY, USA.

Hunter, J.J., O.T. de Villiers, and J.E. Watts. 1991. The effect of partial defoliation on quality characteristics of Vitis vinifera $\mathrm{L}$ cv Cabernet Sauvignon grapes - 1 Sugars acids and $\mathrm{pH}$. S. Afr. J. Enol. Vitic. 12:42-50.

Jones, G.V. 2007. Climate change: observations, projections, and general implications for viticulture and wine production. P. 1-13. In: Proceedings of the Climate and Viticulture Congress, Zaragoza, Spain.

Mateus, N., J.M. Machado, and V. de Freitas. 2002. Development changes of anthocyanins in Vitis vinifera grapes grown in the Douro Valley and concentration in the respective wines. J. Sci. Agric. 82:1689-1695.

Muñoz, R., J. Pérez, P. Pszczolkowski, and E. Bordeu. 2002. Influencia del nivel de carga y microclima sobre la composición y calidad de bayas mosto y vino de Cabernet Sauvignon. Cien. Inv. Agr. 29:115-125.

Nuzzo, V., and M.A. Matthews. 2006. Response of fruit growth and ripening to crop level in dryfarmed Cabernet Sauvignon on four rootstocks. Am. J. Enol.Vitic. 57:314-324.

OIV. 1985. Codes des caractères descriptifs des variétés et espèces de Vitis. Office International de la Vigne et du Vin (OIV), Paris, France. $152 \mathrm{pp}$.

OIV. 1990. Recueil des Méthodes Internationales d'Analyse des Vins et des Moûts Office International de la Vigne et du Vin (OIV). Paris, France.

Ojeda, H., C. Andary, E. Kraeva, A. Carbonneau, and A. Deloire. 2002. Influence of pre- and 
postvéraison water deficit on synthesis and concentration of skin phenolic compounds during berry growth of Vitis vinifera $\mathrm{cv}$. Shiraz. Am. J. Enol. Vitic. 53:261-267.

Petrie, P., and P. Clingeleffer. 2006. Crop thinning (hand versus mechanical) grape maturity and anthocyanin concentration: outcomes from irrigated Cabernet Sauvignon (Vitis vinifera L.) in a warm climate. Austr. J.Grape Wine Res. 12:21-29.

Ryan, J.M., and E. Revilla. 2003. Anthocyanin composition of Cabernet Sauvignon and Tempranillo grapes at different stages of ripening. J. Agric. Food Chem. 51:3372-3378.

Tesic, D., D.J. Wolley, E.W. Hewett, and D.J. Martin. 2001. Environmental effects on cv. Cabernet Sauvignon (Vitis vinifera L.) grown in
Hawke's Bay New Zealand - 1 Phenology and Characterisation of viticulturals environments. Aust. J. Grape and Wine Research 8:15-26.

USDA. 2005. Soil Taxonomy. A basic system of soil classification for making and interpreting soil surveys. Second ed. Agricultural Handbook 436, US Government Printing Office, Washington DC. http://soilsusdagov/technical/classification/ taxonomy. (Accessed: May, 2006).

Watson, B. 2003. Evaluation of winegrape maturity. p. 235-245. In: E.W. Hellman (ed). Oregon Viticulture. Oregon State University Press, Corvallis, Oregon. USA.

Weaver, R.J., and S.B. Mccune. 1960. Influence of Light on Color Development in Vitis Vinifera Grapes. Am. J. Enol. Vitic. 11:179-184. 